\title{
ROAD TRANSPORTATION CHALLENGES IN THE ARCTIC
}

\author{
A. SHOJAEI BARJOUEI, OVE T. GUDMESTAD \& JAVAD BARABADY \\ Department of Technology and Safety, UiT: The Arctic University of Norway, Norway
}

\begin{abstract}
Despite all efforts to mitigate global warming, its rate and magnitude are still rising where transportation is considered to be an important contributor. In the Arctic regions however, unstable weather conditions, strong seasonal variations, and long harsh winters result in additional challenges to transportation in different ways such as those related to environment, human health, safety, and economy. This study deals with challenges related to road transportation in the Arctic regions. With this aim in mind, firstly the effects of weather-related factors, including precipitation, temperature and wind on road transportation are presented. Then, to investigate challenges, a causal analysis utilizing the approach of fault tree analysis (FTA) is conducted in which the related impacts are classified into three categories: environment, health/safety and economy. Accordingly, the critical causes are discussed and mitigating measures are addressed. It is suggested that the holistic review presented in the paper will be useful in identifying the most sustainable ways to decrease negative effects from road transportation in the Arctic.
\end{abstract}

Keywords: road transportation, Arctic region, fault tree analysis, operation and maintenance, environmental impact.

\section{INTRODUCTION}

Unstable weather conditions, strong seasonal variations and long harsh winters are characteristics of the climate in the Arctic regions which imposes challenges to road transportation in different directions such as operation and maintenance, traffic volume, travel time, travel cost, risk of accidents, as well as environmental impacts. Particularly in Norway, many roads are vulnerable to harsh weather due to its topographical characteristics including mountains, deep fjords, lakes and rivers. Generally, time, discomfort and risk are likely to have an influence on cost and volume of traffic. Moreover, availability and high price of alternative routes and modes of transport, type and amount of freight transport as well as challenges related to operation and maintenance are other influential factors on cost and volume of traffic.

Keeping roads and highways open to traffic, limiting emissions from maintenance machinery and impacts of chemicals on air, soil and water are the main challenges of road operation and maintenance in the Arctic [1]. Lower average speed on icy and snow-covered roads increases travel time as well as fuel consumption, which can get worse by improper operation and maintenance [2], [3]. Non-equipped and non-qualified vehicles not only boost air pollution due to higher rate of fuel consumption and $\mathrm{CO}_{2}$ emission, but also impose high risk of accident and consequently injuries and death [4]. Although Norway is one of the safest countries in terms of road transportation, nearly 700 fatal and severely injured accidents in road traffic in 2019 was reported [5]. However, despite the increase in traffic volume, the number of road accidents including fatal and severely injured was reduced by $3 \%$ in 2017 comparing with 2016 and $10 \%$ in 2018 comparing with 2017 . Whilst, there have been no significant changes in 2019 compare to 2018 [5]. Moreover, in the vision of the road sector of the Norwegian Ministry of Transport and Communications, a maximum of 500 killed and severely injured by 2024, and 350 killed and severely injured by 2030 are targeted [6]. 
Electric vehicles (EVs) and hybrid electric vehicles (HEVs) are other contributors to mitigate the impacts of road transportation on global warming and climate change, provided the electricity is generated by renewable resources. Norway is indeed the world leader in the use of EVs which is because of incentives, such as tax exemptions and toll exemptions, considered by the government to persuade people [7], [8]. The Norwegian government has set the goal of zero emission for all new cars by 2025, whilst the same goal is, for example, targeted by Ireland and UK by 2030 and 2040, respectively [9]. However, the function of EVs and HEVs in the Arctic region due to the effect of low temperature on battery power is controversial [10], [11].

The rest of the paper is organized as follows. Section 2 is devoted to the effects of the Arctic weather on road transportation. A causal analysis regarding the challenges associated with road transportation in the Arctic utilizing the approach of FTA is conducted in Section 3. The critical causes and mitigating measures are addressed in Section 4. Eventually, the paper is concluded in Section 5.

\section{EFFECTS OF THE ARCTIC WEATHER ON ROAD TRANSPORTATION}

To address the road challenges in the Arctic, firstly the influence of the Arctic weather conditions on road transportation should be investigated. Precipitation, wind and temperature are critical weather elements in the Arctic that affect road transportation. Since precipitation like snow, rain and fog cause icy and slippery road surface and reduce visibility, users avoid to drive in this situation and they may prefer other transport modes or cancel leisure trips. Consequently, decrease in traffic volume is expected by increase in precipitation. Likewise, wind leads to snowdrifts in snow-covered areas causing limited visibility, narrow roads and eventually closure. Moreover, vehicles may be blown off the road by strong winds, events which are more likely on slippery roads. Therefore, particularly in snow-covered areas and slippery roads, reduction in traffic volume in windy days is expected. The scenario is the same for low temperatures. Extremely cold weather, especially when followed by snow, may cause uncomfortable driving. Hence, low traffic is supposed in low temperature [12]-[14]. Bardal [14] considered a part of European Highway 6 (E6) in Saltfjellet, Northern Norway, to investigate the effects of variation in temperature, precipitation, and wind speed on road traffic volumes for both passenger and freight transportation. Accordingly, it is concluded that the traffic load reduces during adverse weather particularly for passenger transportation; while due to the road conditions and driving difficulties, the transportation costs are considerably increased. In rural areas however, alternative routes and transportation modes are restricted. Therefore, passengers in rural areas might have no option except using the high-cost transportation mode for their daily routines all through the year.

\section{CAUSAL ANALYSIS}

In this section, to identify and analyze the possible causes of the challenges associated with road transportation in the Arctic and investigate the contribution of the basic causes and their interrelationship, the approach of fault tree analysis (FTA) is conducted. FTA is one of the most common approaches to discover the potential hazards and the related root causes utilizing a diagrammatic technique to illustrate the hazard and causes, using symbols as shown in Table 1 [15]. Consequently, the results provide a practical view which not only aids analysts to choose between the root causes with higher contribution, but also is useful for documentation and preparing risk profiles to improve future designs [16].

Maintenance activities on Arctic roads affect soil, air, water, vegetation and biodiversity [17]. Adverse weather, such as low temperature, heavy precipitation, strong wind, fog and clouds influence road traffic volume and risk of accident [14]. Convoy, closure, reduced 
Table 1: Fault tree symbols.

\begin{tabular}{ll}
\hline Logic gate & Description \\
OR-gate & $\begin{array}{l}\text { The output event (above) occurs if at least one of the } \\
\text { input events (below) occurs. }\end{array}$ \\
BND-gate \\
The output event (above) occurs if all input events \\
(below) occur.
\end{tabular}

speed, daylight, and using spiked tyres induce time and monetary costs [14]. Accordingly, a list of basic events that might contribute to the road transportation challenges in the Arctic is provided, which are indeed the events that require no further development of failure causes such as environmental conditions, users' behaviour and basic equipment failures. Moreover, three top challenges comprised of environment, health/safety, and economy are considered, which are eventually caused by combinations of the basic events. The basic events might also indirectly lead to a top challenge by creating challenges in the middle levels called middle events. The basic, middle, and top level events are listed in Tables 2, 3, and 4, respectively. Accordingly, some of the possible scenarios that might lead to a middle or top event are as follows:

- Vehicles are likely to be blown off the road by strong winds on a slippery road as a result of precipitation, low temperature and improper maintenance.

- If the snow on the road is not cleaned and there is strong wind causing snowdrift, this leads to narrow road and restricted visibility. Restricted visibility could result in accident and traffic delays. Additionally, traffic delays are partly responsible for more fuel consumption, air pollution, disease, and increase in travel time.

- Bad driving behaviours such as exceeding speed limit, not keeping the following distance, harshly braking, suddenly turning, stopping on the side of the road may cause accident which contributes to traffic as well as economic impact.

- Low temperature together with using an inappropriate battery might lead to battery discharge. Eventually, roadside service must be called for possibly recharging the battery or towing the vehicle, inducing time and monetary costs.

- Soil and groundwater are to be affected by using improper chemicals. Inappropriate construction design also impacts on soil, groundwater and vegetation. Using studded tyres on dry roads is responsible for local air pollution and respiratory diseases. It also damages the road pavement. 
Table 2: List of basic events.

\begin{tabular}{llll}
\hline Code & Description & Code & Description \\
\hline B01 & Darkness & B13 & Exceeding speed limit \\
B02 & Low temperature & B14 & Not keeping the following distance \\
B03 & Fog/clouds & B15 & Harshly braking \\
B04 & Snow/rain & B16 & Suddenly turn \\
B05 & Strong wind & B17 & Stopping on the side of the road \\
B06 & Inappropriate construction & B18 & Using high-beam headlights \\
& design/material & B19 & Inappropriate battery for cold climate \\
B07 & No fence along the road & B20 & Inappropriate glass cleaner \\
B08 & No straw mats protection & B21 & Inappropriate engine oil \\
B09 & No avalanche and land slide & B22 & Improper gasoline \\
& protection & B23 & Using studded tyres on dry roads \\
B10 & Improper road maintenance & B24 & No available ground/air ambulance \\
& planning & B25 & No regular vehicle checkup \\
B11 & Improper physical cleaning & B26 & Vehicle technical problem \\
B12 & Improper anti-ice/deicer & B27 & High price of alternative \\
& & & routes/modes of transport \\
\hline
\end{tabular}

Table 3: List of middle events.

\begin{tabular}{llll}
\hline Code & Description & Code & Description \\
\hline M01 & Closure & M07 & Narrow road \\
M02 & Convoy & M08 & Vehicles blown off the road \\
M03 & Traffic & M09 & Increased fuel consumption \\
M04 & Accident & M10 & Restricted visibility \\
M05 & Reduced speed limit & M11 & Icy and slippery road surface \\
M06 & Snowdrift & M12 & Avalanche/land slide \\
\hline
\end{tabular}

Table 4: List of top events.

\begin{tabular}{|c|c|c|c|c|c|}
\hline \multicolumn{2}{|c|}{ Environmental impact } & \multicolumn{2}{|c|}{ Health/Safety impact } & \multicolumn{2}{|c|}{ Economic impact } \\
\hline Code & Description & Code & Description & Code & Description \\
\hline En01 & Impact on & $\begin{array}{ll}\text { HSO1 } \\
\text { HSO2 }\end{array}$ & $\begin{array}{l}\text { Fatality } \\
\text { Iniury }\end{array}$ & Ec01 & Increase in travel \\
\hline En02 & $\begin{array}{l}\text { Impact on } \\
\text { vegetation }\end{array}$ & $\begin{array}{l}\mathrm{HS} 03 \\
\mathrm{HS} 04\end{array}$ & $\begin{array}{l}\text { Inconvenience } \\
\text { Disease }\end{array}$ & $\mathrm{Ec} 02$ & $\begin{array}{l}\text { Damage to vehicle/ } \\
\text { freight/infrastructure }\end{array}$ \\
\hline En03 & $\begin{array}{l}\text { Impact on } \\
\text { soil/water }\end{array}$ & & & $\mathrm{Ec} 03$ & Battery discharge \\
\hline En04 & Impact on air & & & & \\
\hline
\end{tabular}

In this regard, all events are hierarchically located at one of the basic, middle, and top levels and fault trees related to environmental, health/safety, and economic impacts are developed as illustrated in Figs 1, 2, and 3. To simplicity, those events that are used in several places in the fault trees, are developed only one time, and in other places are shown as gray rectangular symbols. 


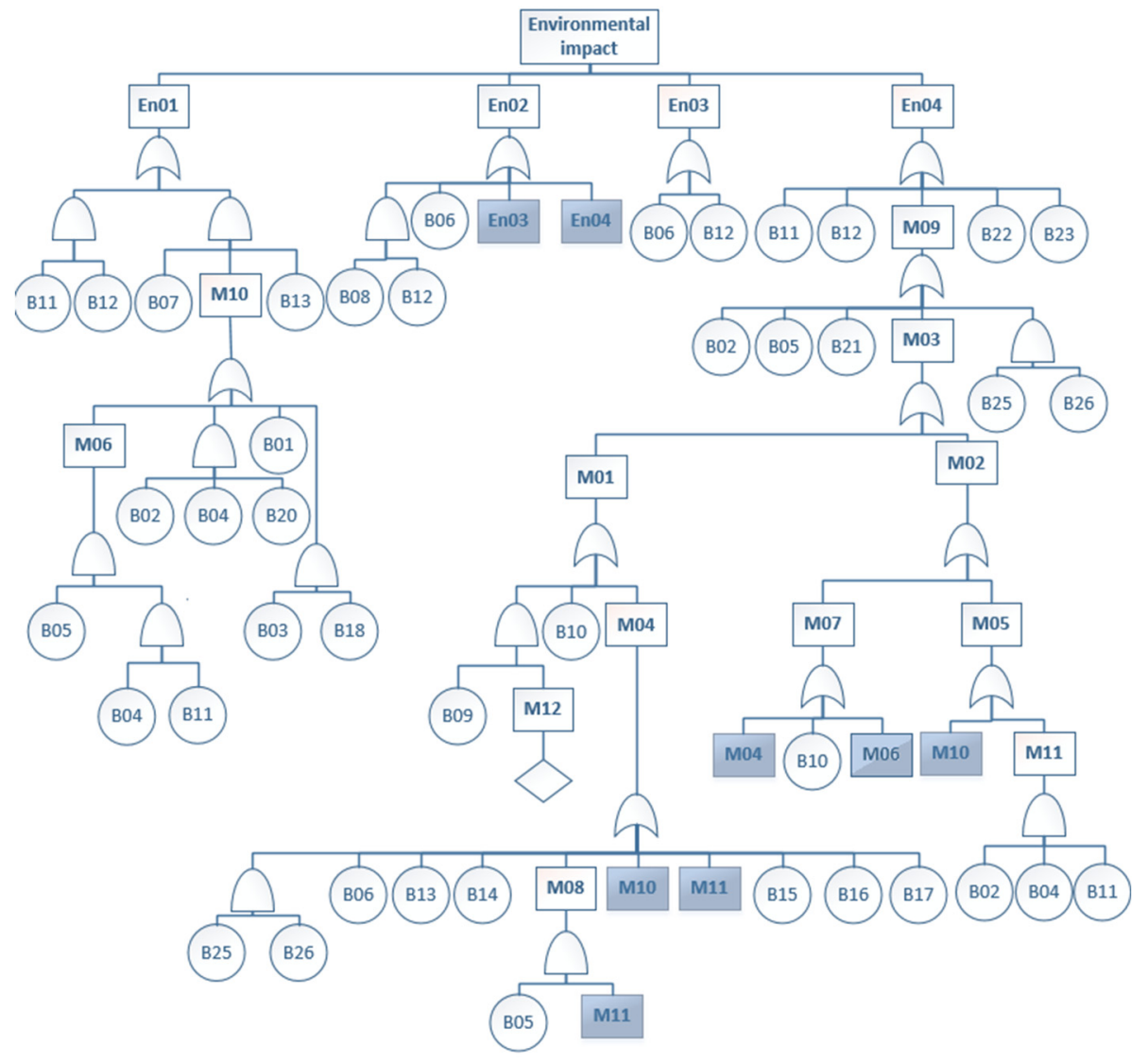

Figure 1: FTA for environmental impacts of road transportation in the Arctic.

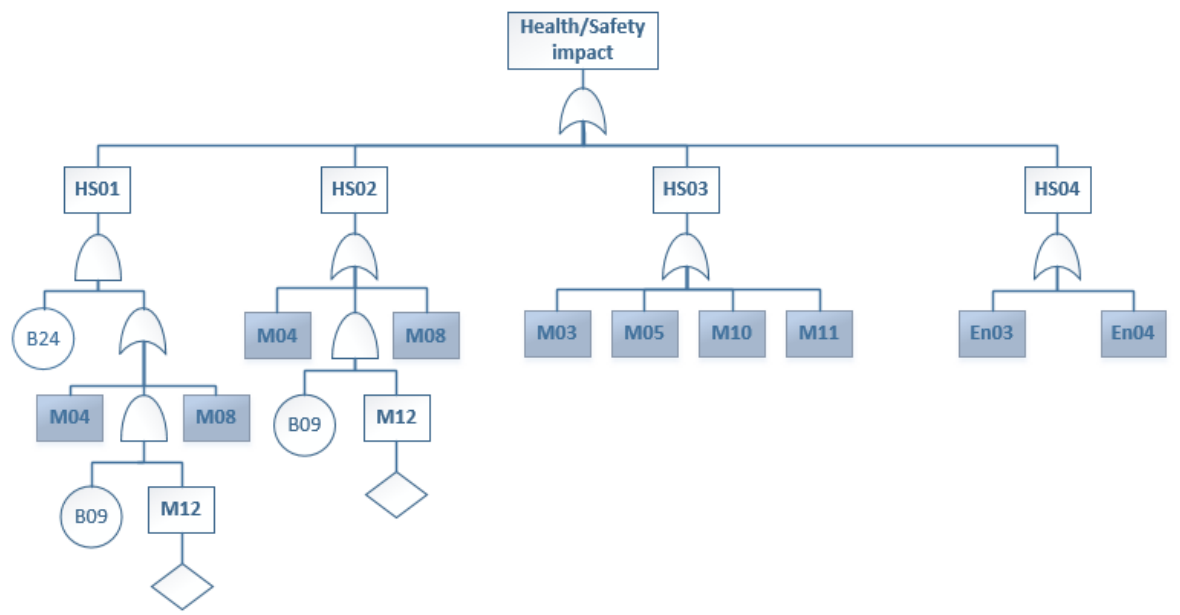

Figure 2: FTA for health/safety impacts of road transportation in the Arctic. 


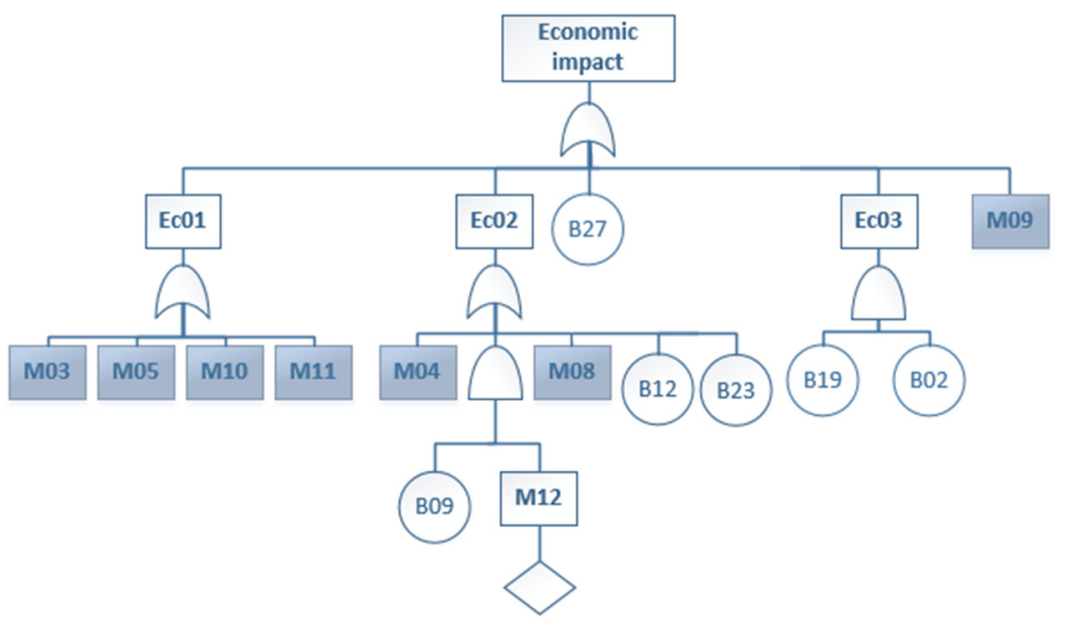

Figure 3: FTA for economic impacts of road transportation in the Arctic.

\section{DISCUSSION}

Although the developed FTA is not quantitative, it provides a schematic view of the contribution of different causes and their interrelationship. Accordingly, the events in higher levels and those that came up in several branches are likely to have higher contributions. For instance, the basic event of "improper anti-ice/deicer" (i.e., B12) came up in all types of environmental impacts (i.e., En01, En02, En03, and En04) and different levels. It also contributes to health/safety (i.e., HS04) and economic impacts (i.e., Ec02). Likewise, the basic event of "using studded tyres on dry roads" (i.e., B23) influences environment (i.e., En02), human health (i.e., HS04), and economy (i.e., Ec02). Accordingly, some of the critical basic and middle events are chosen and addressed in this section.

\subsection{Anti-icing and de-icing chemicals}

To provide open roads with safe and smooth mobility, enhancing friction is a critical measure. Indeed, friction effects between tyres and pavement are the main factors in controlling a vehicle, as friction is influencing directional control, breaking distance and acceleration. Maintaining friction on Arctic roads can be achieved through either using proper tyres or controlling snow and ice.

In addition to physical cleaning, applying anti-icing and de-icing chemicals on heavy traffic roads and sanding on low traffic roads are common ways of snow and ice control in the Arctic. Anti-icing chemicals lower the freezing point of water and consequently prevent pavements from freezing. Additionally, the initial bonding between frozen rain or snow and pavement is prevented by anti-icing. De-icing chemicals are applied to remove snow and ice which have already stuck to the pavement. Therefore, hard crust formation can be prevented and physical ice and snow removal will be easier. Sodium chloride $(\mathrm{NaCl})$, magnesium chloride $(\mathrm{MgCl} 2)$, calcium chloride $(\mathrm{CaCl} 2)$, potassium formate $(\mathrm{KCOOH})$, and calcium magnesium acetate (CMA) are some common anti-icing and de-icing chemicals with different effectiveness and environmental impacts in accordance with precipitation, temperature, and land topology [17]. Hence, determining the appropriate amount and type of chemicals at the right time to obtain the highest effectiveness with respect to low 
environmental impacts is a critical issue in operation and maintenance of roads in the Arctic [18], [19].

Chemicals generally affect soil to the depth of $10 \mathrm{~m}$ from the road surface with significant impact on the first $2 \mathrm{~m}$, although they are detectable up to $50 \mathrm{~m}$. The optimal $\mathrm{pH}$ range for plant growth is [4.5 6.5] while deicers greatly influence soil by increasing alkalinity [20], [21]. Deicers and exhaust fumes from road maintenance can destroy vegetation. Studies show that increasing the volume of deicers to 10 tons $/ \mathrm{km}$ leads to $10 \%$ increase in vegetation loss in areas of high precipitation, with large impact on the first $10 \mathrm{~m}$ distance from road. To reduce the effect of deicers on plants, it is recommended to plant trees at least $2 \mathrm{~m}$ from roads since the deicer effects reduce $50-80 \%$ at this distance. Moreover, straw mats protection as square around trees are useful [22].

The solubility of heavy metals increases by using deicers leading to their mobilization and entering to nearby freshwater ecosystems. Additionally, soil chemistry can be negatively affected by ionic strength as the result of using deicers. Heavy metal mobilization can also threaten freshwater habitats and organisms. It also endangers directly human health and agricultural products by intrusion to groundwater systems [23]. The amount of calcium and chloride in soil increase at the end of winter by melting snow and ice. Consequently, during the growth period of plants in spring and summer, soil is in the highest level of salinity [24].

Deicers additionally contribute to the corrosion of construction materials and vehicle parts such as tyres and brakes [25]. For instance, sulphates in the soil from deicers considerably increase concrete corrosion and therefore sulphate-free deicers should be applied near concrete structures [26].

\subsection{Studded tyres}

Using studded tyres is the other solution to maintain friction and provide safe and smooth mobility on Arctic roads. A study was conducted in five cities in Norway including Oslo, Drammen, Stavanger, Bergen and Trondheim over more than seven years from 1 Jan. 2002 to 31 Aug. 2009 to investigate the influence of reduction in the use of studded tyres and the number of accidents. The results showed that $50 \%$ reduction in the use of studded tyres leads to $3 \%$ increase in the injury accidents reported by police and less than $0.5 \%$ increase in property damage accidents reported by insurance companies [27]. Thus, it is seen that using studded tyres in winter slightly reduces accident rate. However, despite the benefits of using studded tyres on snow and ice, like safety and better handling, these tyres have some potential local impacts due to noise and the spread of particulate matters threatening public health. Particularly on dry roads that are free of snow and ice, the use of studded snow tyres causes pavement deterioration where micro diameter materials are scattered into air along with deicers and sand. It is also estimated that using deicers after each icing weather event leads to around $30 \%$ increase of particle matters. Studded tyres additionally contribute to noise pollution. Estimations show that $20 \%$ reduction in use of studded tyres leads to $1-1.5 \mathrm{dBA}$ reduction in noise emission which is significant for human health.

In order to mitigate the impacts of using studded tyres, some restrictions are considered in different countries. In Norway for instance, drivers are permitted to use studded tyres from 1 Nov. to the first Monday after Easter. In north counties (i.e., Nordland, Troms and Finnmark) however, the permission is from 15 Oct. up to and including 30 Apr. which may be extended based on the weather and road surface conditions [28]. While, in cities in the southern part of the country, a studded tire tax is imposed. 


\subsection{Battery power in low temperatures}

As mentioned, EVs and HEVs are globally accepted solutions to mitigate global warming and climate change, provided the electricity is generated by renewable resources [29]. Whilst, the main drawback of EVs and HEVs in cold climate is rapid battery power loss, which is due to variety of reasons like need to heat the cabin, more travel time in dark winter road, required power for headlights, rear window defroster, and seat heaters. Lithium-ion (Li-ion) cells are the mostly used batteries in today's EVs and HEVs; their highest performance is at pleasant temperature for human (i.e., around $20^{\circ} \mathrm{C}$ ) and as the temperature decreases, their internal components resist to pass current [11]. For instance, the available power from a Li-ion cell at $-20^{\circ} \mathrm{C}$ reduces $40 \%$ in comparison with room temperature for the same current [30].

A widely adopted practice to maintain the battery power and drivability is preheating before driving. However, this approach prohibits instantaneous mobility due to the required time which is around 40 minutes [31]. The performance of Li-ion cells at low temperatures can be attributed to several factors including the mobility of lithium ions in the electrolyte solution (i.e., electrolyte conductivity), electrode thickness, cell design as well as separator porosity and wetting properties. In terms of the electrolyte conductivity, as temperature drops, the motion of ions decreases, leading to a significant rise in internal impedance. Studies on Li-ion electrolytes show that all carbonate-based electrolytes have sufficient conductivity for good performance at low temperatures. Therefore, using this approach improves the performance of Li-ion cells at low temperatures [32].

Zhang et al. [10] introduced another strategy for rapid power restoring as well as regeneration at temperatures as low as $-40^{\circ} \mathrm{C}$. The technique is based on heating the battery internally during regenerative braking and rest periods of driving. Accordingly, the battery restoration and full regeneration will be achieved in 13, 33, 46, 56 and 112 seconds at $0,-10,-20,-30$ and $-40^{\circ} \mathrm{C}$ respectively [31].

\subsection{Emissions from roads in the Arctic}

Climate records show an increasing rate and magnitude of global warming, suggested to be due to greenhouse gases, of which the transportation sector is the main contributor [33], [34]. In Europe, more than a quarter of the Greenhouse gas (GHG) is emitted by the transportation sector [35] while the road transport solely is responsible for $14 \%$ of total global GHG emission. It is worth mentioning here that different emission patterns over the road life cycle is expected. For instance, in roads with significant volumes of traffic, direct emissions from traffic and maintenance activities (i.e., operation and maintenance phase) are the main contributors of GHG. Whilst, in less demanding roads, material and construction phases are the largest sources of GHG [36], [37].

Apart from the traffic, operations and maintenance is responsible for around half of the emissions from a road over its lifetime, in which a third of that is due to pavement and regular winter-related maintenance activities. Winter road maintenance also contributes to some other environmental impacts such as stratospheric ozone depletion, acid rains, emissions of toxic chemicals, and so on [17], [38]. Moreover, the growing demand for mobility and the increased users' expectations to make the roads free of ice and snow early after each weather event have resulted in frequently use of maintenance machineries as well as chemicals and consequently more air pollution and other environmental impacts. 


\subsection{Structure and design of roads in the Arctic}

The structure and design of roads in the Arctic greatly influence the need for ice control and the frequency of need for maintenance activities. Moreover, fuel consumption is affected by road features such as road alignment, rolling resistance and road roughness. Meanwhile, factors like rolling resistance and road roughness are significantly influenced by ice and snow. Therefore, taking into account the climatic factors in the design phase enhances safety of journeys and longevity of roads and reduces the frequency of structural maintenance and pavement [17]. For instance, icing on a road due to surface waters (e.g., shallow groundwater, stream, and springs), and damages due to stormwater from heavy rain or melted snow and ice during the breakup period in spring can be mitigated by improving the design. Although, some changes to improve the road structure and design is possible during the use, however, these changes are restricted and much more expensive.

Stormwater pipes, sewers, gutters, and manholes are some components that have been traditionally considered in the Arctic roads. However, issues like overflow, pipes and gutters blockage due to icing and frost heave damages are particular troubles related to surface water management in the Arctic regions. To this aim, porous pavement, which is surfaced by permeable concrete blocks, is beneficial. Generally, increasing the permeability of surfaces and the storage volume are suitable measures to decline runoff from streets in urban areas in the Arctic regions. Permeability and infiltration capacity of both asphalt and vegetated area vary over time due to parameters such as water and ice content, pore size, heat properties of asphalt and soil, as well as external parameters like solar radiation and air temperature. The infiltration capacity can be maintained over a longer period by proper maintenance. Use of coarser particles like gravel can decrease clogging of drains in Arctic region where sanding is common way to cope with slippery roads [39].

It must be remembered that water stored in permeable layers could cause heave of the roadway during freezing, so drainage is important. Frost, which is a common characteristic of the ground in the Arctic region, is impermeable and therefore surface water cannot penetrate into the ground and eventually ice will easily form on the surface in cold weather. During the early winter, the ground surface which is fed by shallow groundwater gradually begins to freeze and block the ditches and culverts besides the roads. The ice at this stage is thin, with liquid water under its smooth flat surface. In this period, even if the air temperature falls greatly, the ground temperature is still warmer and the underflow is still liquid. As the ground temperature drops, the depth of the frozen ground grows steadily and the second stage of ice forms in the surface leading to drainage blocking. Under this condition, if the permeable asphalt is not physically or chemically cleaned from the first stage of icing, the asphalt begins to be damaged by the formation of the second stage of icing [40].

As mentioned, the traditional measures to mitigate icing such as use of filter blind ditch, fence, dam, pit, ice removal by machine or labor and insulated drainage pipe are not always effective and they are costly and/or labor intensive. A filter blind ditch for blocking ice may easily be frozen and blocked, losing its drainage function. Fence, dam, and pit may have restricted capacity of holding or blocking water and thus ice, due to the topography of the region. Ice removal by machine or labor may cost, contribute to air pollution, or be risky for the labors. The drainage opening of the insulated drainage pipe may be frozen and disabled in the middle of winter. Therefore, a single traditional measure would not successfully prevent icing and updated measures involving several methods, considering the properties of icing in the region should be combined. 


\section{CONCLUSION}

In this study, the challenges of road transportation in the Arctic with respect to the impacts on environment, human health and safety, and economy were considered. For this purpose, the effects of the Arctic weather on road transportation were firstly presented and then causal analysis using the FTA approach was conducted. Consequently, some of the critical challenges including using anti-icing and de-icing chemicals, using studded tyres on dry roads, performance of batteries in low temperature, emissions of traffic and maintenance activities, and structure and design of roads were addressed. Accordingly, it is concluded that due to the vast impacts of anti-icing and de-icing chemicals on air, soil, water, vegetation, human health and infrastructures, their applications should be much reduced by firstly improving the structure and design of roads and secondly developing proper maintenance schedule. Moreover, in the maintenance scheduling, the amount of physical cleaning and chemicals applied should be optimized based on their impacts. Additionally, instead of using studded tyres, using winter tyres, on which their rubber and compound remain flexible in low temperatures and their grooves are wide with small shoulders for proper function on snow and ice, is recommended.

In terms of emission, apart from providing open roads with moderate traffic congestion by developing proper maintenance schedule, using EVs and HEVs seems to be the best solution, provided the electricity is generated by renewable sources, like hydropower. However, the performance of batteries is still required to be improved. Eventually, regarding the structure and design of the roads in the Arctic, neglecting the land topology and the Arctic related features of the construction materials lead to frequent need of physical and chemical cleaning and higher price for reconstruction. Furthermore, considering a single measure would not successfully prevent icing and combining a set of mitigating measures is essential.

Ultimately, sustainable road transportation systems in the Arctic are provided by taking into account the Arctic requirements in structure and design of the roads, effectively applying chemicals, developing proper maintenance schedule, ensuring steady traffic conditions, and minimizing emissions from traffic.

\section{REFERENCES}

[1] Fay, L. \& Shi, X., Environmental impacts of chemicals for snow and ice control: State of the knowledge. Water, Air, and Soil Pollution, 23(5), pp. 2751-2770, 2012.

[2] Hinkka, V., Pilli-Sihvola, E., Mantsinen, H., Leviäkangas, P., Aapaoja, A. \& Hautala, R., Integrated winter road maintenance management: New directions for cold regions research. Cold Regions Science and Technology, 121, pp. 108-117, 2016.

[3] Leden, L., Hamalainen, O. \& Manninen, E., The effect of resurfacing on friction, speeds and safety on main roads in Finland. Accident Analysis and Prevention, 30(1), pp. 75-85, 1998.

[4] Blackcircles.com, 2019. www.blackcircles.com/tyres/winter-tyres.

[5] Statens vegvesen, Årsrapport 2019, Statens vegvesen, Lillehammer, 2020.

[6] Ministry of Transport, National Transport Plan 2018-2029, Norwegian Ministry of Transport and Communications, 2017.

[7] Gibson, C., Why do they love electric cars in the Arctic Circle? BBC, 2016.

[8] Richter, F., Electric mobility: Norway races ahead, Statista, 2019.

[9] Jones, H., What's put the spark in Norway's electric car revolution? Guardian News \& Media Limited, 2018.

[10] Zhang, G., Ge, S., Xu, T., Yang, X.-G., Tian, H. \& Wang, C.-Y., Rapid self-heating and internal temperature sensing of lithium-ion batteries at low temperatures. Electrochimica Acta, 218, pp. 149-155, 2016. 
[11] Eisenstein, P.A., Tesla, Jaguar and Nissan EVs lose range in freezing temps as polar vortex leaves electric car owners out in the cold, CNBC LLC, 2019.

[12] Al Hassan, Y. \& Barker, D.J., The impact of unseasonable or extreme weather on traffic activity within Lothian region, Scotland. Journal of Transport Geography, 7(3), pp. 209-213, 1999.

[13] Datla, S. \& Sharma, S., Impact of cold and snow on temporal and spatial variations of highway traffic volumes. Journal of Transport Geography, 16(5), pp. 358-372, 2008.

[14] Bardal, K.G., Impacts of adverse weather on Arctic road transport. Journal of Transport Geography, 59, pp. 49-58, 2017.

[15] Rausand, M., Risk Assessment Theory, Methods, and Applications, John Wiley \& Sons: New Jersey, 2011.

[16] Aven, T., Risk Analysis: Assessing Uncertainties beyond Expected Values and Probabilities, John Wiley \& Sons: West Sussex, 2008.

[17] Vignisdottir, H.R. et al., A review of environmental impacts of winter road maintenance. Cold Regions Science and Technology, 158, pp. 143-153, 2019.

[18] Fjærestad, J.S., Klein-Paste, A. \& Wåhlin, J., Chemical frost protection of road surfaces: A laboratory investigation. Transportation Research Record, 2674(1), pp. 228-235, 2020.

[19] Giudici, H., Klein-Paste, A. \& Wåhlin, J., Influence of $\mathrm{NaCl}$ aqueous solution on compacted snow: Field investigation. Journal of Cold Regions Engineering, 34(1), 04019015, 2020.

[20] Czerniawska-Kusza, I., Kusza, G. \& Dużyński, M., Effect of deicing salts on urban soils and health status of roadside trees in the Opole region. Environmental Toxicology, 19(4), pp. 296-301, 2004.

[21] Gałuszka, A., Migaszewski, Z.M., Podlaski, R., Dołęgowska, S. \& Michalik, A., The influence of chloride deicers on mineral nutrition and the health status of roadside trees in the city of Kielce, Poland. Environmental Monitoring and Assessment, 176(1-4), pp. 451-464, 2011.

[22] Fan, Y., Weisberg, P.J. \& Nowak, R.S., Spatio-temporal analysis of remotely-sensed forest mortality associated with road de-icing salts. Science of The Total Environment, 472(15), pp. 929-938, 2014.

[23] Schuler, M.S. \& Relyea, R.A., A review of the combined threats of road salts and heavy metals to freshwater systems. BioScience, 68(5), pp. 327-335, 2018.

[24] Pedersen, L.B., Randrup, T.B. \& Ingerslev, M., Effects of road distance and protective measures on deicing $\mathrm{NaCl}$ deposition and soil solution chemistry in planted median strips. Journal of Arboriculture, 26(5), pp. 238-245, 2000.

[25] Hääl, M.-L., Sürje, P. \& Rõuk, H., Traffic as a source of pollution. Estonian Journal of Engineering, 14(1), pp. 65-82, 2008.

[26] Padilla, V., Ghods, P. \& Alfantazi, A., Effect of de-icing salts on the corrosion performance of galvanized steel in sulphate contaminated soil. Construction and Building Materials, 40, pp. 908-918, 2013.

[27] Elvik, R. \& Kaminska, J., Effects on accidents of reduced use of studded tyres in Norwegian cities, Institute of Transport Economics, Oslo, 2011.

[28] Statens vegvesen, Important dates for vehicle owners, 2019. www.vegvesen.no/kjoretoy/Eie+og+vedlikeholde/Viktige+datoer.

[29] Nazir, S. \& Wong, Y., Energy and pollutant damage costs of operating electric, hybrid, and conventional vehicles in Singapore. Energy Procedia, 14, pp. 1099-1104, 2012.

[30] Bugga, R., Smart, M., Whitacre, J. \& West, W., Lithium ion batteries for space applications. 2007 IEEE Aerospace Conference, Big Sky, MT, USA, 2007. 
[31] Zhang, G., Ge, S., Yang, X.-G., Leng, Y., Marple, D. \& Wang, C.-Y., Rapid restoration of electric vehicle battery performance while driving at cold temperatures. Journal of Power Sources, 371, pp. 35-40, 2017.

[32] Jaguemont, J., Boulon, L., Dube, Y. \& Poudrier, D., Low temperature discharge cycle tests for a lithium ion cell. 2014 IEEE Vehicle Power and Propulsion Conference, Coimbra, Portugal, 2014.

[33] UNFCCC, Summary of the Paris Agreement, in United Nations Framework Convention on Climate Change, Paris, 2015.

[34] IPCC, Global warming of $1.5^{\circ} \mathrm{C}$. An IPCC special report on the impacts of global warming of $1.5^{\circ} \mathrm{C}$ above pre-industrial levels and related global greenhouse gas emission pathways, in the context of strengthening the global response to the threat of climate change, Intergovernmental Panel on Climate Change, 2018.

[35] Chapman, L., Transport and climate change: A review. Journal of Transport Geography, 15(5), pp. 354-367, 2007.

[36] Santos, J., Ferreira, A. \& Flintsch, G., A life cycle assessment model for pavement management: road pavement construction and management in Portugal. International Journal of Pavement Engineering, 16(4), pp. 315-336, 2015.

[37] Galatioto, F., Huang, Y., Parry, T., Bird, R. \& Bell, M., Traffic modelling in system boundary expansion of road pavement life cycle assessment. Transportation Research Part D: Transport and Environment, 36, pp. 65-75, 2015.

[38] Ebrahimi, B. et al., Tank-to-wheel emissions from articulated steered wheel loaders. 7th Transport Research Arena TRA, Vienna, Austria, 2018.

[39] Stenmark, C., An alternative road construction for stormwater management in cold climates. Water Science and Technology, 32(1), pp. 79-84, 1995.

[40] $\mathrm{Yu}, \mathrm{W}$. et al., Icing problems on road in Da Hinggangling forest region and prevention measures. Cold Regions Science and Technology, 42(1), pp. 79-88, 2005. 